\title{
Developing Digital Rubrics of Six Tasks of KKNI IR 4.0-Based For TEFL Subject
}

\author{
Nora Ronita Dewi ${ }^{1}$, Masitowarni Siregar ${ }^{2}$, Anggraini Thesisia Saragih ${ }^{3}$ \\ ${ }^{1,2,3}$ English Education Study Program, State University of Medan
}

\begin{tabular}{|c|c|}
\hline ARTICLE INFO & \multirow{17}{*}{$\begin{array}{l}\text { This study is aimed at developing rubrics of six tasks of Teaching } \\
\text { English as a Foreign Language (TEFL) the subject of the KKNI } \\
\text { Industrial Revolution 4.0-based of an English Education Study } \\
\text { Program at UNIMED. The objectives of this research are to analyze } \\
\text { the rubrics of TEFL subject used at the } 3^{\text {rd }} \text { semester of English } \\
\text { Education Study Program and develop the appropriate KKNI rubrics } \\
\text { based on the students' needs. This study is mainly focused on } \\
\text { developing Critical Book Report, Critical Journal Report, } \\
\text { Engineering Ideas, Mini Research, and Projects rubrics. Research and } \\
\text { Development applied in this research and the results show that the } \\
\text { rubrics used in the } 3^{\text {rd }} \text { semester at English Education Study Program } \\
\text { is developed through implementing the simplification of R\&D. The } \\
\text { rubrics indicated low competency for the students after analyzing the } \\
\text { questionnaires given. New rubrics are designed to answer the needs } \\
\text { of the students. Generally, the existing TEFL rubrics are less relevant } \\
\text { for the needs of } 3^{\text {rd }} \text { semester students. In terms of descriptor rubrics, } \\
\text { they are not suitable with the needs of the Lesson Plan and the tasks } \\
\text { of TEFL rubrics needed by the students are irrelevant for their needs } \\
\text { where the topics or contents used in the course book are useful in the } \\
\text { learning outcome of this subject. }\end{array}$} \\
\hline Article history: & \\
\hline Received Jun 27, 2019 & \\
\hline Revised Sep 15, 2019 & \\
\hline Accepted Oct 1, 2019 & \\
\hline Keywords: & \\
\hline & \\
\hline TEFL, & \\
\hline Six Tasks of KKNI, & \\
\hline & \\
\hline & \\
\hline Clonflict of Interest: & \\
\hline & \\
\hline None & \\
\hline Funding: & \\
\hline None & \\
\hline & \\
\hline
\end{tabular}

Corresponding Author: Nora Ronita Dewi, English Education Study Program, State University of Medan, E-mail: noradewi@unimed.ac.id

Copyright $($ C Association of Language Teachers in Southeast Asia. All rights reserved

\section{Introducation}

Changes in the world are now entering the era of the industrial revolution 4.0 or the fourth world industrial revolution where information technology has become the basis in human life. Everything becomes borderless with unlimited use of computing power and data, because it influences the development of the internet and massive digital technology as the backbone of the movement and connectivity of humans and machines. In addition, the existence of the ASEAN Economic Community, the readiness of human resources (HR) is an important factor that must be considered in education, especially higher education, has a very significant role in preparing skilled human resources and ready to compete in the free market.

English is a basic skill that must be possessed by every graduate of higher education in facing global competition. In addition to the low competency of students' comprehension, the problem is becoming more serious because the courses in the English Language Study Program at the State University of Medan have also not been subjected to meaningful review and development. In fact, learning outcomes of this subject at each level of teaching have not been described in the form of measurable statement formulations based on the needs assessment. Each teacher uses their own teaching material so that the competencies produced vary greatly. This directly results in the problem of the standardization of English competence of graduates both internally in relation to quality standardization and externally in relation to the competencies expected by users. 
The lecturers in English Education Study Program, English Language and Literature Department, Faculty of Language and Art (FBS), Medan State University (Unimed) always develop instruments of teaching based on a curriculum that is often reviewed and updated adjusted to the needs of the market or graduate users. The alumni of study programs are certainly the wider community in the world. With the Presidential Decree No. 8 on the Indonesian National Qualification Framework (KKNI), has encouraged the English Education Study Program to develop a curriculum with the guidelines for KKNI oriented Higher Education Curriculum so that the State University of Medan, especially English Language Study Program has implemented the KKNI curriculum since 2016 to ensure accountability organizers of education in the equality of qualifications / competencies of graduates in accordance with their level of education and to ensure the achievement of the quality of education in Indonesia are at the same level as the quality of education in other countries.

Lecturers often face a common problem that there are still quite a lot of lecturers, especially in teaching TEFL who have not used this teaching material based on KKNI perfectly. Actually, there are many factors that cause this problem, both the factors within the lecturers itself and the factors outside the lecturers. Therefore, the researcher concludes that the teaching of TEFL seems appropriate when connected with the role of the lecturers in referring to the KKNI curriculum reference in conducting the learning process.

This research was conducted by developing an assessment tool with reference to the PBM process in the IQF curriculum which involves 6 assignments, namely Routine Tasks (TR), Critical Journal Review (CJR), Critical Book Report (CBR), Engineering Idea (Engineering Idea), Project and Mini Research (Mini Research) in teaching TEFL. Through this assignment, able to answer the preparation of tertiary institutions in the era of the Industrial Revolution delivered by Mennristekdikti, research on the development of appraisal based on 6 assignments in the KKNI is expected to be able to provide understanding and skills to lecturers about developing appraisal tools related to mastering the competency of lecturers' main task in planning, presenting / implementing, evaluating learning, and making improvements in the quality of learning programs by implementing ICT in facing the challenges of the fourth industrial revolution through blended learning designs.

\section{Literature Review}

\subsection{Indonesian National Qualification Framework}

Curriculum evaluation and review in per-Higher education is a strategic activity in the context of developing and improving the quality of education in study programs in per-State or Private Higher Education in Indonesia. Print said that the curriculum must always be reviewed in an effort to update the curriculum. The basic reason, according to Murray Print, was stated "the very substance of schooling and the raison d'etre for teachers in schools" in improving the quality of education and spirit is the curriculum. For 5 years, the concept of Competency Based Curriculum. KKNI has become part of the learning process in Higher Education in accordance with Ministerial Decree No. 232 / U / 2000. The development of the Higher Education curriculum should refer to the KKNI (Indonesian National Qualification Framework), because education regulations are standardized through the KKNI.

The English Education Study Program curriculum has undergone four changes. Initially, the English Language Study Program ran PTKSN curriculum, then Kurnas (National Curriculum). In 2005, it was replaced with the KBK (Competency Based Curriculum), then revised again in 2007 to KBK 2007. In 2008 it was revised again to the KBK Block System, with consideration of basic competencies for the needs of Educators in secondary schools, professional competencies, demands of stake holders (user), and work group. Giving 6 types of assignments to students the implementation of KKNI . These tasks include Routine Tasks, Critical Book Review, Critical Journal Review, Engineering Ideas, Mini Research and Projects.

\subsection{TEFL}

Berns (1990) defined foreign language learning as learning a target language in a country that does not use this language as a speech community. Thus, in a foreign language learning context, there are few opportunities for learners to employ the target language outside the classroom because the language (English, in this case) is not used as the main device of communication among people. When a target language is seldom used outside the classroom, input and language use in the classroom are essential (Suryati, 2013).

According to Sulistiyo (2009) there are several factors creating difficulties for TEFL in Indonesia. First, EFL teachers must teach students in large classes, often with more than 50 students. Although the definition of a 'large' class of language learning varies (Wright, 2005), this number is not ideal for a language classroom. Second, not all students who attend English classes are motivated. English is a compulsory subject, which means that students must learn the language for examination purposes; however, their exposure to English occurs for only for approximately two hours per week. Students' low motivation and minimal English learning hours are obstacles not only for teachers, but also for students as learners. 


\subsection{Six KKNI-based Assignments \\ 1. Routine Tasks}

Routine assignments in lectures that use KKNI as a curriculum require all students to accept and work on routine assignments given by their lecturers.

\section{CBR (Critical Book Report)}

From its name, CBR (Critical Book Report) is a task in which we are required to criticize 2 or more accredited pieces, namely the main book in English where this first book we will mention the main book and the second is a comparative book in Indonesian language and language English, depending on the ability of all fellow students.

\section{CJR (Critical Riview Journal)}

CJR (Critical Riview Journal) is a task that demanding students to be able to criticize a national or international journal and review it again in order to find a new understanding that is easier to understand by those who review or who read the journal review.

\section{Engineering Ideas}

Idea Engineering is the task of one of the tasks in the curriculum of the KKNI of education which requires students to create a new idea, or engineer an existing idea to be better or can be said to be more efficient than before.

\section{Mini Research}

The purpose of this Mini Research is to get the results of a study carried out in a scope that is not too large, how to get students trained to go directly into the field of conducting research which is an embodiment of the lecture material they have received.

\section{Project}

The objective of this project's task is to train students to work independently or in groups in creating a product that is beneficial to society.

\subsection{E-Learning}

E-learning is a system or concept of education that utilizes information technology in teaching and learning. Learning is arranged with the aim of using an electronic or computer system so that it can support the learning process (Michael, 2013: 27). The distance learning process by combining principles in the learning process with technology (Chandrawati, 2010). The learning system used as a means for teaching and learning process carried out without having to face to face directly between teachers and students (Ardiansyah, 2013).

\section{Method}

\subsection{Design}

The research design used in this study was Research and Development (R\&D). The aim of this study was to develop and validate educational products such as strategy, method, and media. Borg and Gall (1983:772) stated that the cycle of $R \& D$ process consists of studying research findings pertinent to the product to be developed, developing the products based on these findings, field testing it in the setting where it will be used eventually, and revising it to correct the deficiencies found in the filed-testing stage. The developing of the educational products will keep going until the products are ready and match the objective of the study.

\subsection{The Subject of the Research}

Development of KKNI-based assessment tools for teaching TEFL in the English Education Study Program Dik. C 2018 Unimed uses research and development design (Research and Development). This method is a research method used to produce products and test the effectivity of these products (Sugiono, 2010). This research was conducted in the KKNI-based teaching materials validation test on the development of 6 TEFL Subjects in the English-Unimed Education Study Program, Willem Iskandar Pasar V Medan street. Furthermore, data collection techniques in this study were interviews and questionnaire distribution by 2 TEFL lecturers and 30 students by applying TEFL material

\subsection{Instrument of Data Collection}

The instruments used in collecting the data were questionnaire and interview.

1. Questionnaire

The questionnaire was given to the students to do the need analysis. Furthermore, a questionnaire of validation was also given to experts to validate the rubrics.

2. Interview

The interview was done to the lecturers in order to find the problems in TEFL class and how the lecturers overcome the problems. 


\subsection{Technique of Collecting Data}

The data were collected by using qualitative and quantitative methods. The qualitative data were obtained from the questionnaire of the students and the interview with TEFL lecturers. The quantitative data was the percentage form of the validation questionnaire from the experts.

\subsection{Technique of Data Analysis}

The data were analyzed in two forms, qualitative and quantitative data analysis. For the qualitative data, the researcher analyzed the students' questionnaire and the interview data to find students' needs and evaluate the available rubrics of assignment. The data were collected in the table then the findings and conclusion were described based on that. Then, the quantitative data were obtained from the validation questionnaire from the experts. Based on those analyses, the rubrics was developed to be a recommended as standard criteria of rubrics in TEFL subject. For the quantitative data, the researcher calculated the questionnaire result by changing it to percentage form to find which answer got the highest result in order to know the students' need in TEFL.

\subsection{The Procedure of Rubrics Development}

The strategy was developed through 6 stages based on Borg and Gall's research theory (1983), they are:

1. Gathering data and information.

Here, the researcher did an observation in order to find the problems faced by the students in TEFL class.

The observation was done at English-Unimed Education Study Program, particularly for the fourth semester students.

2. Need Analysis

The researcher analyzed the data from the students' questionnaire and the interview with TEFL lecturers. The questionnaire was given to know students' needs in learning, while the interview was done to collect detail information about the learning process.

3. Designing Rubrics

After analyzing the student's need, researcher developed the rubrics suitable for the students in TEFL class.

4. Validating and evaluating new rubrics the experts.

The rubrics that has been developed was validated by the experts to know its effectiveness in learning TEFL. The experts were experienced senior lecturers in TEFL Subjects at Post Graduate Study at Universitas Negeri Medan and TEFL lecturers from English Education Study Program of Unimed.

5. Revising the Rubrics

After the rubrics has been judged, it was revised based on the experts' suggestions to get the best suitable results for the students in learning.

6. Final Product

The final product that has been revised will be implemented in the teaching-learning process to help students in TEFL class.

\section{Findings \& Discussion}

Development of 6 KKNI-based assignments on the implementation of blended learning in TEFL courses developed to produce the final product, they are: (1) Gathering data and information; (2) Analyzing the needs of student questionnaires by observing TEFL and $6 \mathrm{KKNI}$ assignments in the form of Routine Tasks, Critical Journal Review, Critical Book Report, Engineering Idea, Mini Research and Project.; (3) Developing 6 KKNI rubric assignments; (4) Validating to experts; (5) Revising the results obtained; (6) Producing a final product in the form (draft) of learning website development (e-learning) in the TEFL course.

Based on the data obtained from the aspect of knowledge, the understanding of students in completing the 6 assignments of KKNI TEFL courses has been understood by $70 \%$ of students, in assigning 6 TEFL assignments lecturers, have less interaction with students in giving clear instructions and lack understanding of explanations from lecturers concerned, in gathering $6 \mathrm{KKNI}$ assignments as many as $73.33 \%$ of students had difficulties, the suitability of instructional media in TEFL courses, $63.67 \%$ of students said they were less appropriate. This shows that lecturers and students interact less in the sense that students are more accepting (passive). In the learning media in the TEFL course, $40 \%$ of students prefer learning to use online rather than manuals (face to face), $90 \%$ of students say it is necessary. The use of Native Speaker recordings for explaining the material in the TEFL course, students tend to want that, according to the findings of $73.33 \%$. The layout on the display of TEFL subject matter, $46.67 \%$ of students want material that can motivate them to learn the course.

The final product of this research is developing 6 KKNI tasks in the form of Routine Tasks (TR), Critical Journal Review (CJR), Critical Book Report (CBR), Engineering Idea (Engineering Idea), Mini Research 
(Mini Research) and Project (Project) the learning website (e-learning) in the TEFL course in manuals and blended learning, by collaborating both ways the development of 6 tasks is expected to be achieved. The development includes:

Table 5.1.1. Development of 6 KKNI assignments in TEFL courses through e-learning

\begin{tabular}{|c|c|c|c|}
\hline \multirow{2}{*}{ No. } & \multirow{2}{*}{6 Task of KKNI } & \multicolumn{2}{|c|}{ Subject of TEFL } \\
\hline & & Manual & Developing \\
\hline 1 & Routine Task (TR) & $\begin{array}{l}\text { The lecturers gives a worksheet } \\
\text { and explains the assignment } \\
\text { (face to face) }\end{array}$ & $\begin{array}{l}\text { Upload Routine Task (TR) / worksheet } \\
\text { rubric, student work made. }\end{array}$ \\
\hline 2 & $\begin{array}{l}\text { Critical } \\
\text { Review }\end{array}$ & $\begin{array}{l}\text { The lecturers give two books to } \\
\text { be criticized and instructions } \\
\text { (face to face). }\end{array}$ & $\begin{array}{l}\text { Upload e-books that will be criticized } \\
\text { and workmanship instructions, discuss } \\
\text { through discussion forums. }\end{array}$ \\
\hline 3 & $\begin{array}{l}\text { Critical Journal } \\
\text { Review }\end{array}$ & $\begin{array}{l}\text { The lecturers give two journals } \\
\text { / articles to be criticized and } \\
\text { explained their knowledge } \\
\text { (face to face). }\end{array}$ & $\begin{array}{l}\text { Upload the e-journal / article that will } \\
\text { be criticized and the working } \\
\text { instructions are discussed through a } \\
\text { discussion forum. }\end{array}$ \\
\hline 4 & $\begin{array}{l}\text { Engineering Idea } \\
\text { (RI) }\end{array}$ & $\begin{array}{l}\text { Lecturers with students } \\
\text { discuss and determine the } \\
\text { scope of ideas that can be } \\
\text { engineered and their } \\
\text { instructions (face to face). }\end{array}$ & $\begin{array}{l}\text { Upload instructions for ideas to be } \\
\text { engineered and discuss through } \\
\text { discussion forums. }\end{array}$ \\
\hline 5 & $\begin{array}{ll}\text { Mini } & \text { Research } \\
\text { (MR) } & \end{array}$ & $\begin{array}{l}\text { Lecturers and students discuss } \\
\text { and determine relevant research } \\
\text { topics and instructions (face to } \\
\text { face). }\end{array}$ & $\begin{array}{l}\text { Upload the research topic instructions } \\
\text { that will be specified and discuss } \\
\text { through discussion forums. }\end{array}$ \\
\hline 6 & Project $(\mathrm{P})$ & $\begin{array}{l}\text { Lecturers and students } \\
\text { discuss and determine which } \\
\text { projects will be carried out. If } \\
\text { a student chooses his own } \\
\text { topic, s/he must obtain } \\
\text { lecturers approval and } \\
\text { instructions (face to face). }\end{array}$ & $\begin{array}{l}\text { Upload instructions for ideas that will be } \\
\text { developed into project material and } \\
\text { discuss through discussion forums. }\end{array}$ \\
\hline
\end{tabular}

\section{Gathering Data and Information}

The data and information in this research were obtained by doing the primary observation to the TEFL class in the English Education Study Program Dik. C 2018 Unimed. The fact showed that during the teaching and learning process at that faculty, lecturers taught students by using conventional method and seldom using media to stimulate students. Sometimes, the lecturers did use the Power Point Presentation (PPT) to deliver the material but it was not sufficient. These habits that the lecturers did during the teaching and learning process caused the students to have lacks understanding to the material. This then led the students to have a low score. To overcome this problem, students needed the audio-visual media in order to motivate them in learning English, especially in TEFL.

\section{Need Analysis}

The need analysis was conducted to obtain the information of the target needs and learning needs by distributing the questionnaires to the students and doing an interview with the lecturers. The detailed results of the need analysis are presented as follow:

\section{a. The Description of the Respondents}

The questionnaire for the need analysis was distributed to the students of Dik. C 2018 class of EnglishUnimed Education Study Program. The respondents of this research were thirty five students.

Table 4.1 Data of the Respondents of the Research

\begin{tabular}{cccccccc}
\hline Respondents & \multicolumn{2}{c}{ Sex } & \multicolumn{3}{c}{ Age } \\
& Male & Female & 12 & 13 & 14 & 15 & 16 \\
35 students & 20 & 15 & 7 & 13 & 13 & 1 & 1 \\
\hline
\end{tabular}

\section{b. The Result of Needs Analysis}


The questionnaire was divided into three aspects to get the target needs and learning needs. The first aspect was to look for the general information. There were six questions provided for this part. The next aspect was to find out the target needs. Here, it consisted of learners' goals in learning TEFL, learners' wants of speaking activities, and learners' view about difficulties in learning English. There were six questions in this part. The last aspect was to find out the learning needs consisting of input, setting and the development of digital rubrics. There were four questions. Hence, the following is the detailed result of need analysis.

\section{1) General Information}

This section contained questions that revealed the general information of the students. The detail result of this section could be seen as follows:

Table 4.2 Learners' General Information in Learning TEFL

\begin{tabular}{|c|c|c|c|c|c|}
\hline No & Question & Items & $\mathbf{N}$ & $\mathbf{F}$ & $\begin{array}{c}\text { Percentages } \\
(\%)\end{array}$ \\
\hline \multirow[t]{4}{*}{1.} & \multirow{4}{*}{$\begin{array}{l}\text { According to you, TEFL } \\
\text { subject is. . }\end{array}$} & a. Very important & \multirow[t]{4}{*}{35} & 16 & 45.71 \\
\hline & & b. Important & & 14 & 40 \\
\hline & & c. Less important & & 4 & 11.42 \\
\hline & & d. Not important & & 1 & 2.85 \\
\hline \multirow[t]{4}{*}{2.} & \multirow{4}{*}{$\begin{array}{l}\text { According to you, how is your } \\
\text { comprehension in TEFL } \\
\text { subject? }\end{array}$} & a. Very competent & \multirow[t]{4}{*}{35} & 0 & 0 \\
\hline & & b. Competent & & 7 & 20 \\
\hline & & c. Less competent & & 27 & 77.14 \\
\hline & & d. Incompetent & & 1 & 2.85 \\
\hline \multirow[t]{4}{*}{3.} & \multirow{4}{*}{$\begin{array}{l}\text { According to you, how often } \\
\text { do you do discuss TEFL } \\
\text { subject? }\end{array}$} & a. Very often & \multirow[t]{4}{*}{35} & 1 & 2.85 \\
\hline & & b. Often & & 3 & 8.57 \\
\hline & & c. Sometimes & & 31 & 88.57 \\
\hline & & d. Never & & 0 & 0 \\
\hline \multirow[t]{4}{*}{4.} & \multirow[t]{4}{*}{ How is TEFL activity in class? } & a. Very fun & \multirow[t]{4}{*}{35} & 10 & 28.57 \\
\hline & & b. Fun & & 14 & 40 \\
\hline & & c. Just so-so & & 11 & 31.42 \\
\hline & & d. Not fun & & 0 & 0 \\
\hline \multirow[t]{4}{*}{5.} & \multirow{4}{*}{$\begin{array}{l}\text { Are the course book and } \\
\text { worksheet sufficient to make } \\
\text { you understand a topic in } \\
\text { learning TEFL } \\
\text { ? }\end{array}$} & a. Yes & \multirow[t]{4}{*}{35} & 21 & 60 \\
\hline & & b. Sometimes & & 7 & 20 \\
\hline & & c. No & & 7 & 20 \\
\hline & & d. Not at all & & 0 & 0 \\
\hline \multirow[t]{4}{*}{10.} & \multirow{4}{*}{$\begin{array}{l}\text { In teaching and learning } \\
\text { process, has the lecturers used } \\
\text { an interesting media? }\end{array}$} & a. Ever & \multirow[t]{4}{*}{35} & 20 & 57.14 \\
\hline & & b. Sometimes & & 4 & 11.42 \\
\hline & & c. Rare & & 10 & 28.57 \\
\hline & & d. Never & & 1 & 2.85 \\
\hline
\end{tabular}

From the table above, it is concluded that the students were already aware the importance of TEFL subject. Most of the students chose TEFL subject is very important (45.71\%). Even though they already realized it, their TEFL understanding is still poor (77.14\%). Most of the students justified they do a discussion of TEFL theory rarely $(88.57 \%)$.

Further, the students confess that TEFL teaching and learning process is fun (40\%). They also contended that by using only course book and worksheet are sufficient to make them understand the lesson (60\%). Further, the lecturers also has ever displayed an interesting media according to them $(57.14 \%)$.

\section{2) Target Needs}

Target needs a deal with the question what knowledge and abilities the learners will require being able to perform to the required degree of competence in the target situation. The target needs cover necessities, lacks, and wants.

a) Necessities

The purpose of this questionnaire is to find out what the learners need in the target situation for their job at the time or in the future (Hutchinson and Waters, 1987). Besides giving the questionnaire, the researcher also doing an interview with TEFL lecturers. The result of necessity gained from the questionnaire were about their goal in learning this subject. The detailed result could be seen in the following Table.

Table 4.3 Learners' Necessities in Learning English Recount Speaking 


\begin{tabular}{|c|c|c|c|c|c|}
\hline No & Question & Items & $\mathbf{N}$ & $\mathbf{F}$ & $\begin{array}{c}\text { Percentages } \\
(\%)\end{array}$ \\
\hline \multirow[t]{4}{*}{6.} & $\begin{array}{l}\text { My goal in learning } \\
\text { TEFL subject is. . . }\end{array}$ & $\begin{array}{l}\text { a. To increase my TEFL theory } \\
\text { understanding }\end{array}$ & 35 & 14 & 40 \\
\hline & & $\begin{array}{l}\text { b. To make me confident when } \\
\text { managing the class }\end{array}$ & & 17 & 48.57 \\
\hline & & $\begin{array}{l}\text { c. To be able to apply TEFL theory in } \\
\text { English class correctly }\end{array}$ & & 3 & 8.57 \\
\hline & & $\begin{array}{l}\text { d. Other : To be able to manage the } \\
\text { class and understand TEFL theory }\end{array}$ & & 1 & 2.85 \\
\hline
\end{tabular}

Based on the table above, most of the students chose to make them confident when managing the class (48.57\%). Referred to the observation done in English-Unimed Education Study Program, it was shown that the students were unable to manage the class, so that's why they chose it as their goal. Because TEFL theory with a bad class management can lead to a misunderstanding. The second answer chosen by the students was to increase my TEFL theory understanding (40\%). Only three students chose to apply TEFL theory in English class correctly.

\section{3) Learning Needs}

Learning needs can be defined as what learners need to do to learn something. To obtain learning needs, the researcher observed some aspects, such as their comprehension input, preference and rubrics development for this subject.

Table 4.6 TEFL Input Preference

\begin{tabular}{|c|c|c|c|c|c|}
\hline No & Question & Items & $\mathbf{N}$ & $\mathbf{F}$ & $\begin{array}{c}\text { Percentages } \\
(\%)\end{array}$ \\
\hline \multirow[t]{4}{*}{11.} & \multirow{4}{*}{$\begin{array}{l}\text { The learning input that I prefer in } \\
\text { learning TEFL subject is }\end{array}$} & a. Pictures & \multirow[t]{4}{*}{35} & 8 & 22.85 \\
\hline & & b. Videos & & 16 & 45.71 \\
\hline & & $\begin{array}{l}\text { c. Magazine, newspaper, } \\
\text { and other printed media }\end{array}$ & & 10 & 28.57 \\
\hline & & $\begin{array}{l}\text { d. Other: with computer or } \\
\text { handphone game media }\end{array}$ & & 1 & 2.85 \\
\hline
\end{tabular}

Table 4.7 TEFL Activity Preference

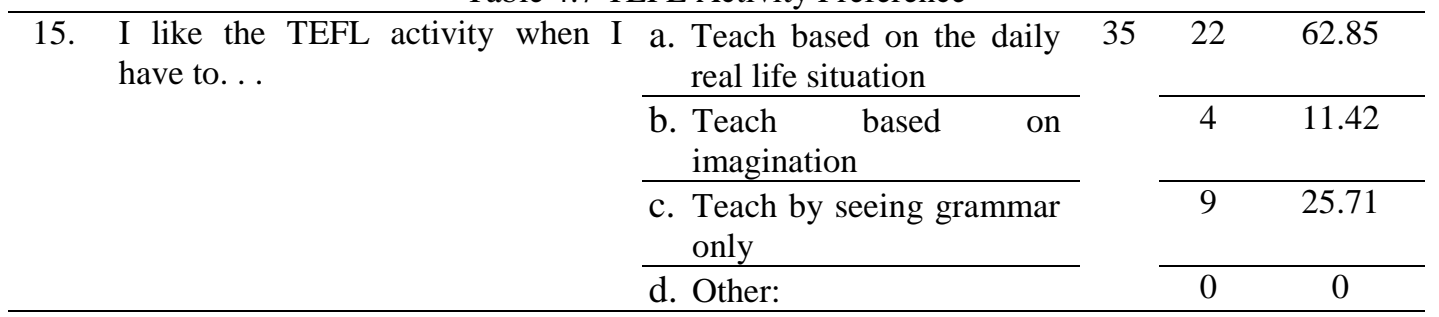

Table 4.8 TEFL Application Preference

\begin{tabular}{|c|c|c|c|c|}
\hline \multirow[t]{4}{*}{ 16. I prefer to teach English when. . . } & $\begin{array}{l}\text { a. I'm with colleagues } \\
\text { without lecturer }\end{array}$ & 35 & 1 & 2.85 \\
\hline & $\begin{array}{l}\text { b. I have some colleagues to } \\
\text { teach with }\end{array}$ & & 26 & 74.28 \\
\hline & c. Someone asks me to teach & & 6 & 17.14 \\
\hline & $\begin{array}{l}\text { d. Other: } \\
\text { - When someone asks } \\
\text { me and in the English } \\
\text { class in the school } \\
\text { - I'm alone with my } \\
\text { imagination }\end{array}$ & & 2 & 5.71 \\
\hline
\end{tabular}


Table 4.9 Rubrics Development for TEFL Subject

\begin{tabular}{|c|c|c|c|c|c|c|}
\hline \multirow{4}{*}{12.} & \multirow{4}{*}{$\begin{array}{l}\text { If there is a rubric consists of } \\
\text { explanation, task, and description, } \\
\text { will you be interested in learning } \\
\text { TEFL subject? }\end{array}$} & a. Very interested & & \multirow[t]{4}{*}{35} & 26 & 74.28 \\
\hline & & b. Just so-so & & & 6 & 17.14 \\
\hline & & $\begin{array}{ll}\text { c. Interested but } \\
\text { enthusiastic }\end{array}$ & not & & 3 & 8.57 \\
\hline & & d. Not at all & & & 0 & 0 \\
\hline
\end{tabular}

Based on the data above, students are interested to learn by using a learning media. Most of the students chose videos $(45.71 \%)$ as the media to learn. Video is an audio-visual media consisted of moving pictures and sound. By using a video as a learning media, teaching and learning process become more attractive and it can motivate students to learn. The students also preferred to teach based on the daily real life situation $(62.85 \%)$. It is probably because when someone is asked about something that they did, it will be easier for him/her to explain it. Further, by relating the material to their real life situation will make them memorize the material even better. Then, the students need some kind of situation that will make them understand. More than half students want to teach more when they have colleagues to teach with $(74.28 \%)$. As we know, to practice our skill in teaching then we need to speak more and more. By having colleagues (classmates) to teach with will make us easier to speak, respond, and correct each other's mistakes.

In interview session, lecturer said that she only used manual media, such as books, and worksheets to teach TEFL subject. According to her, those media were sufficient since the students' understanding of this lesson is still poor. She rarely used any digital media to teach in class because she thought that the students needed to learn the basic more. Further, she found the obstacle in teaching and learning process because the students have lack motivation to learn. For the students, this TEFL is a hard lesson to learn. Even though the students realized that learning this is important, yet their desire to learn is poor. The lecturers said that according to her observation while teaching in class, only a few percentage of the students show their participation. The rest just become passive in class.

The interview excerpts from the English lecturers could be seen as follows.

I : (what kind of rubrics that you designed in teaching TEFL subject? Is that enough to help you in teaching learning process?)

$\mathrm{R} \quad$ :(I designed the six compulsory tasks of TEFL as other lecturers' like Routine Tasks, Critical Book Review, Critical Journal Review, Engineering Ideas, Mini Research, and Project, and I have no standard description yet.)

I : (What are the obstacles you've found related in designing the rubrics)

ET : (Sometimes, I doubted to decide the rubrics description regarding to the task itself. I had some references to make the standard one with some colleagues, but I don't think that's the correct description for each task).

(Interview excerpts)

\section{Validating to Expert}

After finishing the vlog media, then experts evaluated the product in terms of material and media aspects. This validating process is aimed to know whether the product is already appropriate or not to be applied as the learning media for teaching speaking recount text to grade VIII students of the English-Unimed Education Study Program. The experts were given a validation questionnaire. This questionnaire has five scales; very good (5), good (4), fair (3), less (2) and very less (1).

Furthermore, the result of the calculation was measured based on the feasibility criteria proposed by Sugiyono (2012). The criteria are shown in the table below:

Table 4.10 Percentage of Feasibility Criteria for Rubrics Description

\begin{tabular}{ll}
\hline Scores & Categories \\
\hline $81 \%-100 \%$ & Very Good \\
\hline $61 \%-80 \%$ & Good \\
\hline $41 \%-60 \%$ & Fair \\
\hline $21 \%-40 \%$ & Poor \\
\hline$\leq 20 \%$ & Very Poor \\
\hline
\end{tabular}

There were 23 questions in the validation questionnaire. There were fifteen questions for the material aspect and 8 questions for the media aspect. The comments and suggestion box was prepared at the end of the 
questionnaire. Here, the experts can give their comments and suggestions related to the material and media aspects to make the vlog media better. There were two experts involved in this rubrics evaluation, The result of validation is described as follow:

Table 4.12 The Data of Expert's Validation to Rubrics Description aspect

\begin{tabular}{|c|c|c|c|c|c|}
\hline \multirow{2}{*}{ No } & \multirow{2}{*}{ Item Assessed } & \multicolumn{2}{|c|}{ Expert } & \multirow{2}{*}{ Percentages $(\%)$} & \multirow{2}{*}{ Criteria } \\
\hline & & $\mathrm{I}$ & II & & \\
\hline 1. & $\begin{array}{l}\text { The developed rubrics fit the core } \\
\text { competencies in TEFL objects of } \\
\text { learning. }\end{array}$ & 5 & 4 & 90 & Very Good \\
\hline 2. & $\begin{array}{l}\text { The learning objectives which will } \\
\text { be achieved cover the basic } \\
\text { competencies. }\end{array}$ & 5 & 5 & 100 & Very Good \\
\hline 3. & $\begin{array}{l}\text { The rubrics description fits the } \\
\text { learning objectives which will be } \\
\text { achieved. }\end{array}$ & 4 & 4 & 80 & Good \\
\hline 4. & $\begin{array}{l}\text { The developed rubrics fit the } \\
\text { learners' need in TEFL. }\end{array}$ & 4 & 4 & 80 & Good \\
\hline 5. & $\begin{array}{l}\text { The developed rubrics are easy to } \\
\text { understand. }\end{array}$ & 4 & 4 & 80 & Good \\
\hline 6. & $\begin{array}{l}\text { The developed rubrics have } \\
\text { standard description criteria. }\end{array}$ & 4 & 4 & 80 & Good \\
\hline 7. & $\begin{array}{l}\text { The description used have } \\
\text { been in conformity of the } \\
\text { standard criteria }\end{array}$ & 4 & 4 & 80 & Good \\
\hline 8. & $\begin{array}{l}\text { Language used fit } \\
\text { appropriate English grammar } \\
\text { rules. }\end{array}$ & 4 & 4 & 80 & Good \\
\hline 9. & $\begin{array}{l}\text { Ways to show ideas, } \\
\text { thoughts, use a clear and } \\
\text { understandable language. }\end{array}$ & 4 & 5 & 90 & Very Good \\
\hline 10 & $\begin{array}{l}\text { Topics in the TEFL } \\
\text { Materials are presented } \\
\text { attractively and suitable with } \\
\text { the learners' needs. }\end{array}$ & 5 & 5 & 100 & Very Good \\
\hline 11 & $\begin{array}{l}\text { The developed rubrics } \\
\text { support learners' initiation } \\
\text { and creativity to give ideas } \\
\text { and thoughts. }\end{array}$ & 5 & 4 & 90 & Very Good \\
\hline 12 & $\begin{array}{l}\text { The developed rubrics are } \\
\text { highly relevant to the } \\
\text { learners' needs. }\end{array}$ & 5 & 4 & 90 & Very Good \\
\hline 13 & $\begin{array}{l}\text { There are examples and } \\
\text { exercises which are suitable } \\
\text { with the material explained. }\end{array}$ & 5 & 4 & 90 & Very Good \\
\hline 14 & $\begin{array}{l}\text { The rubrics encourage students to } \\
\text { motivate in learning. }\end{array}$ & 5 & 4 & 90 & Very Good \\
\hline 15 & $\begin{array}{l}\text { The rubrics descriptions are } \\
\text { understandable to students. }\end{array}$ & 5 & 4 & 90 & Very Good \\
\hline & An Overall Assessment & 68 & 63 & 87.33 & Very Good \\
\hline
\end{tabular}

From the table above, it could be concluded that the media is feasible to teach speaking recount text for the eighth grade students of the English-Unimed Education Study Program. The average score for the overall assessment for the material aspect is $87.33 \%$. According to the Quantitative Data Conversion proposed by Sugiyono (2012), the score belongs to the very good category with the interval score $81 \%-100 \%$. 
Table 4.13 The Data of Expert's Validation to Rubrics Description

\begin{tabular}{|c|c|c|c|c|c|}
\hline \multirow{2}{*}{ No } & \multirow{2}{*}{ Item Assessed } & \multicolumn{2}{|c|}{ Expert } & \multirow{2}{*}{$\begin{array}{c}\text { Percentages } \\
(\%)\end{array}$} & \multirow{2}{*}{ Criteria } \\
\hline & & $\mathrm{I}$ & II & & \\
\hline 1. & $\begin{array}{l}\text { The quality of Rubrics in } \\
\text { Routine Tasks is generally good } \\
\text { and developed relevantly }\end{array}$ & 5 & 4 & 90 & Very Good \\
\hline 2. & $\begin{array}{l}\text { The quality of Rubrics in Critical } \\
\text { Book Review is generally good } \\
\text { and developed relevantly }\end{array}$ & 5 & 5 & 100 & Very Good \\
\hline 3. & $\begin{array}{l}\text { The quality of Rubrics in Critical } \\
\text { Journal Review is generally } \\
\text { good and developed relevantly }\end{array}$ & 5 & 5 & 100 & Very Good \\
\hline 4. & $\begin{array}{l}\text { The quality of Rubrics in } \\
\text { Engineering Ideas is generally } \\
\text { good and developed relevantly }\end{array}$ & 5 & 5 & 100 & Very Good \\
\hline 5. & $\begin{array}{l}\text { The quality of Rubrics in Mini } \\
\text { Resesarch is generally good and } \\
\text { developed relevantly }\end{array}$ & 5 & 5 & 100 & Very Good \\
\hline 6. & $\begin{array}{l}\text { The quality of Rubrics in Project } \\
\text { is generally good and developed } \\
\text { relevantly }\end{array}$ & 5 & 4 & 90 & Very Good \\
\hline & An Overall Assessment & 30 & 28 & 97 & Very Good \\
\hline
\end{tabular}

Based on the table above, the score for the overall assessment of the rubrics description is $97 \%$. This score is considered as very good category $(81 \%-100 \%)$ according to the Quantitative Data Conversion proposed by Sugiyono (2012). The experts decided that the rubrics is already feasible to TEFL subject to the fourth semester students of English-Unimed Education Study Program. Some revisions are needed to make the rubrics better.

\section{Conclusion}

Teaching English as Foreign Language materials needed by students according to their needs where flexibility in working and collecting six tasks KKNI namely Routine Tasks (RT), Critical Journal Review (CJR), Critical Book Report (CBR), Engineering Idea (EI), Mini Research (MR), and Project used in learning materials that are relevant and useful in learning development that will be needed in 6 KKNI tasks are: upload material, upload 6 KKNI assignments, upload Rubrics, connecting notifications, discussion forums. KKNI-based learning that is implied by blended learning allows time, distance, space, repository, and learning styles of students and lecturers to be more effective and efficient.

\section{References}

Borg and Gall. (1983). Educational Research an Introduction. Cambridge: CUP

Brown, D. (2004). Language assessment: principles and classroom practices. America: Longman

Brown, H. D. (2001). Teaching by Principles-An Interactive Approach to Language Pedagogy Second Edition. San Francisco: Longman.

BSNP. (2010). Panduan Pengembangan Indikator. Retrieved from https://lugtyastyono60.files.wordpress.com/2012/08/panduan-pengembangan-indikator.pdf

Chennat, S. (2014). Classroom Strategies For Developing English Language Skills In Children With Dyslexia At Elementary Level: An Analytical Study. International journal of research in applied vol. 2, issue 6, june 2014, 27-38

Essossomo, S.M. (2013). The English Language Teaching Enterprise In The Posclonial Cameroom: A Focus On The Framework Of Need Analysis. Basic research journal of education research and review ISSN 2315-6872 Vol 2 (9) pp. 124-133

Harsono. (2005). Pengantar Problem-based Learning. Edisi kedua, Medika-Fakultas Kedokteran Universitas Gadjah Mada.

Hasan S. Hamid. (2014). Kerangka kualifikasi nasional indonesia (kkni) dan pengembangan kurikulum S2 pendidikan IPA. https://adpgsdindonesia.files.wordpress.com. 
June, T. N. C. (2005). Nature Of Curriculum. The Hongkong Institute of Education. Retrieved from www.ied.edu.hl/aclass/

Kusnandar. (2013). Penilaian Autentik (Penilaian Hasil Belajar Peserta Didik Berdasarkan Kurikulum 2013 Suatu Pendekatan Praktis Disertai dengan Contoh. Jakarta: PT. Raja Grafindo Persada

Liao, Y. Issues Of Validy And Reliability In Second Language Performance Assessment. Columbia university working papers in TESOL applied linguistics 4(2)

Lunenburg, F. C. (2011). Theorizing About Curriculum: Conception And Definitions. International journal of scholarly academic intellectual diversity, Vol. 13. No. 1

Murray Print, (1992). Curriculum development and design (second edition). Sidney: Allen \& Unwin.

Nasution, Teknologi Pendidikan (Jakarta: PT. BumiAksara, 2008), 99

Nunan, David. (1999). Second Lnguage Teaching \& Learning. Boston: Heinle \& Heinle.

Peraturan Menteri Pendidikan dan Kebudayaan Republik Indonesia Nomor49 Tahun 2014 Standar Nasional Pendidikan Tinggi

tentang

Richards, Jack C. and Rodgers, Theodore S. (2001). Approaches and Methods in Language Teaching. Second Edition. New York: Cambridge University Press.

Sugiyono. 2012. Methodology of Quantitative, Qualitative Research, and R\&D. Bandung: Alfabeta.

http://www.tugaspedia.com/2017/06/7-tips-dan-trik-cara-mengerjakan-tugas.html

http://edel.staff.unja.ac.id/blog/artikel/Pengertian-Blended-Learning.html

https://www.kajianpustaka.com/2014/06/pengertian-karaktiristik-dan-manfaat-elearning.html

http://e-dufiesta.blogspot.co.id/2008/06/pengertian-e-learning.html

http://www.elearningnc.gov/about_elearning/what_is_elearning/

http://elearning.unpad.ac.id Powered by Joomla! Generated: 4 May, 2009, 01:15

http://id.wikipedia.org/wiki/Pembelajaran_elektronik 